\title{
Early Childhood Education and Care System in Finland
}

\begin{abstract}
In Finland, Early Childhood Education and Care (ECEC) includes day care arrangements offered to families (care) along with goal-oriented early childhood education (early education and teaching) provided for children prior to transitioning to primary education. ECEC is therefore seen to build a coherent starting phase within the continuum of lifelong learning. ECEC follows the "educare" principle, which emphasizes the simultaneous consideration for children's education, teaching, and care as the foundation of pedagogical activity, which is at the same time strongly rooted in the idea of learning and development as a holistic experience. The aim of this article is to provide an overview of the Finnish ECEC system, introduce its societal, organizational and curricular preconditions and discuss the current tensions and challenges faced.
\end{abstract}

Keywords: Early Childhood Education and Care, Education system, Curriculum, Pedagogy.

\section{System edukacji i opieki wczesnodziecięcej w Finlandii}

\begin{abstract}
Abstrakt
W Finlandii system edukacji i opieki wczesnodziecięcej (ECEC) obejmuje opiekę dzienną oferowaną rodzinom (opiekę) oraz ukierunkowaną na cel edukację wczesnodziecięcą (wczesna edukacja i nauczanie) zapewnianą dzieciom na etapie przed przejściem do szkoły podstawowej. W związku z tym, ECEC buduje spójną fazę początkową w ramach uczenia się przez całe życie. ECEC kieruje się zasadą „educare” kładącą nacisk na równoczesne uwzględnianie edukacji, nauczania i opieki nad dziećmi jako podstawy działalności pedagogicznej, która jest jednocześnie silnie zakorzeniona w idei uczenia się i rozwoju, jako doświadczenia holistycznego. Celem tego artykułu jest przedstawienie fińskiego systemu edukacji i opieki wczesnodziecięcej, zaprezentowanie jego warunków społecznych, organizacyjnych i programowych oraz omówienie napięć i wyzwań, jakie w nim obecnie występują.
\end{abstract}

Słowa kluczowe: system edukacji i opieki wczesnodziecięcej (ECEC), system edukacyjny, program nauczania, pedagogika.

* Department of Education, University of Jyväskylä, Finland. 


\section{Introduction}

Early Childhood Education and Care (ECEC) in Finland refers to systematic and goal-oriented education, teaching, and care provided to children, where children's holistic development is considered and the role of pedagogy is of particular importance (Early Childhood Education and Care Act 580/2015). ECEC is also strongly value-based. The core values that guide ECEC are derived from the United Nations Convention on the Rights of the Child (1989), which essentially emphasizes the primary nature of the child's best interest; acknowledging the child's opinion; the child's right for well-being, care and protection; the child's right for equality, parity and non-discrimination. The early childhood as a stage of life is considered valuable in itself. ECEC operates through ten goals laid down in the Early Childhood Education and Care Act (580/2015), which steer and shape the daily practice in ECEC. To start with, ECEC shall provide equal opportunities for all children to attend ECEC, which is provided in a healthy and safe environment that promotes development and learning. The individual child is at the heart of ECEC and one of the goals is to promote each child's holistic growth, development, health and wellbeing in age- and developmentally appropriate ways. This requires recognizing and taking into consideration the child's individual needs of support and organizing accordingly appropriate support in ECEC through multi-professional collaboration. The child's own voice and self-determination are supported and ECEC, in its own part, ensures the child's opportunities to participate and to have an impact on issues concerning their own lives. Stable relationships between the child and ECEC staff are ensured with a child-centered way of interacting with the child. Furthermore, ECEC strives toward developing the child's collaborative and interaction skills, promoting cooperation in peer groups and guiding the child toward ethically responsible and sustainable activity, acknowledgment of other people and participation in the society. Thus, in the wider context, ECEC supports the constructive growth of future citizens.

The goals also set a clear stance toward supporting children's holistic growth and learning dispositions: the goal of ECEC is to support the child's learning preconditions and to promote fulfillment of lifelong learning and educational equality. This is done by implementing multifaceted pedagogical activities (based on play, physical activity, arts and cultural heritage) that enable positive learning experiences. Pedagogical underpinnings and expectations are further laid down in the recently revised Core Curriculum for Early Childhood Education and Care (2016). Scaling the pedagogical activities along children's personal and group level needs and age-related requirements is an integral part of ECEC pedagogy, a process which is highly dependent on the competence of the ECEC staff.

Finally, the Finish ECEC system is based on the idea that ECEC supports parents in the task of raising their child. Indeed, a child comes to ECEC with their previous life experiences that are strongly connected to the attachment and interactions between the child and their parents or guardians. At best, collaboration 
with the child and their parents/guardians enhances the child's balanced and holistic development and wellbeing also in ECEC. Particular emphasis is put on parental collaboration with young children just entering the ECEC.

\section{Roots and preconditions of the Finnish ECEC}

The first kindergarten and crèche were established in the city of Jyväskylä in 1863, in accordance with the first class teacher seminar (Eerola-Pennanen, Vuorisalo, Raittila 2017: 13). During the following two decades several institutions for young children were established, but the official start of Finnish ECEC dates back to 1888, when Hanna Rothman founded the first public kindergarten in Helsinki. The goal was strongly rooted in social pedagogy and the Fredrich Fröbel's principles of children's growth, development and learning and the pedagogical means to support them were emphasized (Hänninen, Valli 1986). Kindergartens soon found their place in the society, taking care of children from the poorest environments during parents' working hours (Eerola-Pennanen, Vuorisalo, Raittila 2017: 13). The role of ECEC as the source of social welfare for disadvantaged families strongly defined Finnish ECEC during the following decades.

In the 1960s, due to heavy industrialization, women's participation in the labor force in particular became more and more active. This was also the main driving force to further improve the day care system. As a consequence, in the early 1970s, the legislation on children's day care determined Finnish ECEC as a combination of day care and early education (Children's Day Care Act and Decree 1973) and kindergartens and crèches were unified. Early childhood education and care became an integral part of the labor market and family policy. This in turn had a number of positive effects, including the widespread establishment of day care services (Karila 2012: 584), even though families' social and economic grounds long continued to determine the child's access to ECEC, especially during the 1970s.

In 1990, all parents of children up to the age of three were entitled to choose either to have a place for their child in day care provided by their local authority or to receive a child home care allowance, i.e. 'cash-for-care'. In 1996, the subjective, unconditional right to day care was extended to cover all children under school age. This universal right was in force until 2015, when it was reduced to 20 hours per week, mainly due to the government's budget cuts. At the same time, however, municipalities continued to have autonomy to decide not to implement the reduction in case their own financial situation allowed it. Just recently, the Finland's Council of State (Puroila, Kinnunen, Keränen 2017) published a report where ECEC leaders in municipalities and cities in Finland evaluated the financial and perceived impact the limiting of the subjective right had in their administrative regions. One of the core conclusions was that due to different approaches towards the subjective right in the municipalities and cities, the planned savings would not be achieved at 
the national level. Furthermore, several ECEC leaders reported their concern about going toward a direction where the ECEC system becomes unequal for children, families and ECEC staff (ibidem).

\section{The policy goals of ECEC}

The Finnish ECEC system has clear policy goals (Kahiluoto 2009). Firstly, from the perspective of social policy, the ECEC system provides equal opportunities for all children, but also facilitates equal opportunities for women and men in terms of participation in the society. Secondly, from the perspective of employment policy, ECEC allows both parents to access the labor market (ibidem). In general, Finnish parents are active workers: for instance, in 2014, 73.6\% of married women with children (under 7 years of age), and $89.3 \%$ of married men with children (under 7 years of age) were employed (Pasila 2014). Furthermore, in Finland, it is generally more typical that parents of young children also work full-time rather than parttime (OECD 2006). Finally, from the perspective of educational policy (Kahiluoto 2009), ECEC provides the possibility for all children to receive early education and care which can aid in guaranteeing an equal start for all children and in laying the foundation for success later in life.

Some tensions between the policy goals have emerged across time (ibidem) while discussing the core purpose of ECEC. For instance, the younger the children are, the more easily the attendance to ECEC tends to be justified in terms of care while parents work (employment policy) rather than in terms of the possibility for children to receive early education and care (educational policy).

\section{Child Care Benefits for the Families}

Finland uses the Nordic welfare state principles and methods, which are based on the state's responsibility for its citizens (Määttä, Uusiautti 2012: 292). Thus, both home care of the children and ECEC are arranged and primarily funded by central and local government (Heinämäki 2008). When a child is born, the parents have the possibility to remain home with the baby with maternity/paternity/parental allowance. Maternity allowance is paid by the Social Insurance Institution of Finland (KELA) to the mother for 105 workdays (about 4 months) from the beginning of her maternity leave (around one month before the baby is born). Paternity allowance is payable during paternity leave for 54 working days. Up to 18 days of that can consist of a period in which both the father and the mother stay at home. Parental leave begins after maternity leave. Either the mother or the father can take parental leave, or the parents can take turns. During parental leave, KELA pays a parental allowance for 158 working days. The parents can also work part-time and look after the child for half a day in turns. For this period, KELA pays partial parental allowance to both parents. 
Once parental leave is over, either the mother or the father can stay home with the child with child home care allowance (paid by KELA). The parents are entitled to this allowance until the child turns three years of age, and it is used by a significant number of families in Finland. Some Finnish municipalities pay an additional municipal supplementary benefit to financially support the home care of children in order to encourage parents to take care of their children at home and thus, lessen the demand for municipal day care (Miettunen 2008). However, there is a large variation between municipalities concerning the provision of the supplement and its amount (Lahtinen, Selkee 2016: 12-13), which may have consequences for the parents' decision between staying home with the child and using the ECEC services. In addition, a child benefit is paid for children under 17 who live in Finland. Its amount depends on the number of eligible children in the household.

\section{Provision of ECEC services}

The provision of ECEC services depends on the needs of the families within the municipality. Figure 1 summarizes the Finnish ECEC system and illustrates the provision of different forms of ECEC services.

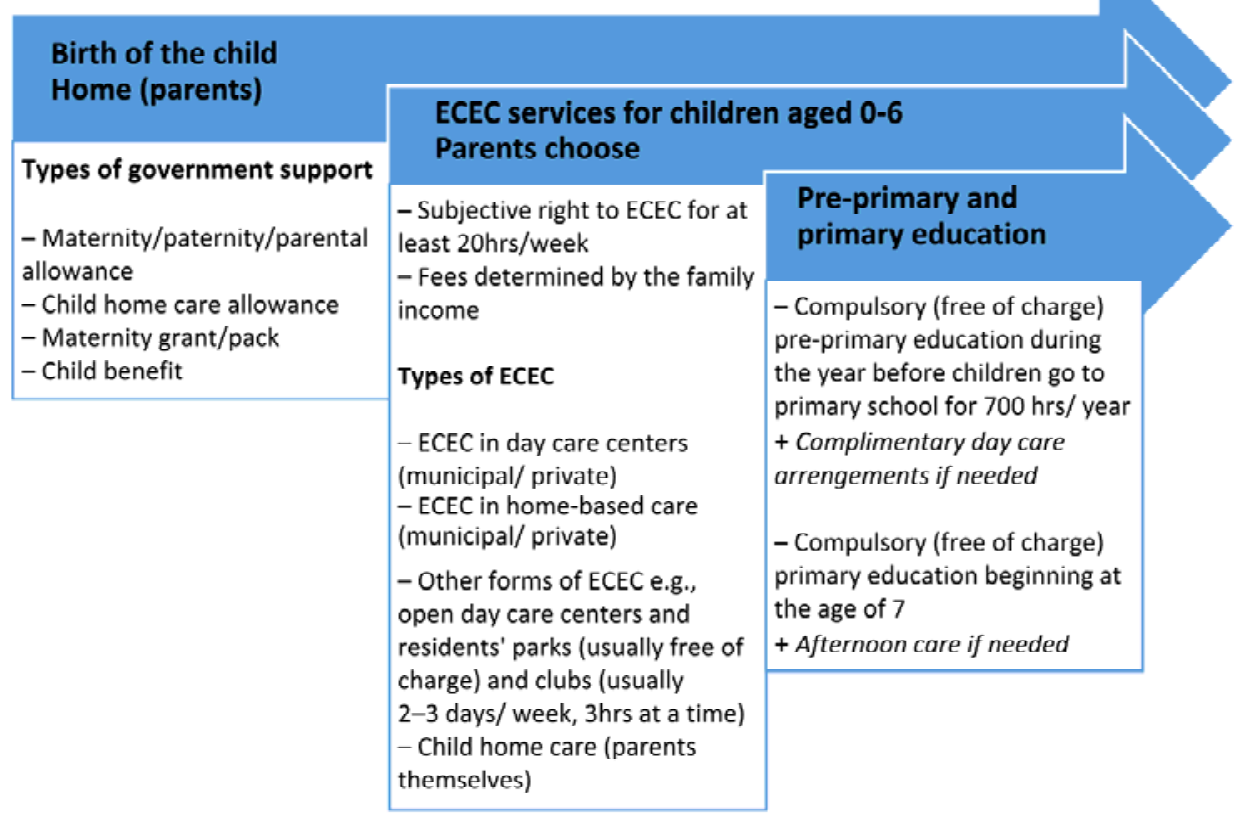

Figure 1. Overview of the Finnish ECEC system 
The most commonly used form of ECEC is municipal day care, either in day care centers (around 68\% of the children), or at municipal childminder (homebased care) (8.4\%) (FINEEC 2017), or at other forms of ECEC (7.2\%). Altogether $83.7 \%$ of children attend municipal day care (FINEEC 2017). The percentage of children in private ECEC (16.2\%) has somewhat increased during the past two years (FINEEC 2017; Säkkinen, Kuoppala 2016: 1) and there are private ECEC services provided in 57\% of the Finnish municipalities (FINEEC 2017). Home-based care is a particularly popular form of ECEC among families with younger children and is often recommended as the first form of ECEC by municipalities. However, the overall trend is that the use of home-based care is decreasing (Rutanen et al. 2014: 131), possibly due to closing down of the municipal family day care in several municipalities.

As a consequence of global changes in working life and the tendency for societies to be open around the clock, children's day care arrangements are also in a state of flux. Around 7\% of Finnish children attend flexibly scheduled ECEC, where both parents, or a single parent, work non-standard hours. Although many countries nowadays offer extended hours of day care, only Finland has a publicly provided, law-based system guaranteeing ECEC during non-standard as well as standard working hours (Rönkä et al. 2017). Municipal ECEC centers normally provide both part-time and full-time services from 6 or 7 am to 5 or $6 \mathrm{pm}$, depending on local childcare needs. Extended hours or overnight and weekend care is provided in some centers only.

\section{Children's attendance to ECEC}

At the end of 2015, there were altogether 245650 Finnish children attending ECEC, which equals 68\% of 1-6-year-old children (Säkkinen, Kuoppala 2016). There are large differences in the number of children enrolled in ECEC (both municipal and private ECEC) in different age groups: only $0.7 \%$ of children under 1 were enrolled in ECEC (reference year 2015). This is due to the majority of children being taken care of at home on the parental allowance. The attendance rate in ECEC increases as children grow older: $28 \%$ of 1 -year-olds and 54\% of 2-year-olds attend ECEC. Furthermore, up to $79 \%$ of 5-year-olds are already part of ECEC. As many as $69 \%$ of children in pre-primary education (6-year-olds) attend ECEC in addition to the preprimary education (free of charge) which is used by practically the whole age cohort. When these figures are contrasted for instance with OECD attendance rates (reference year 2014), it is clear that, on average, Finnish 3-5-year-old children attend ECEC to a lesser extent than children of similar age in other OECD countries (OECD 2016: 308). The attendance is as high as the OECD average amongst 6-yearolds (compulsory pre-primary education). Modest attendance to ECEC is a prevailing trend in Finland, even though the attendance rates have somewhat increased 
when compared to the situation in 2005 (ibidem: 308). It has been suggested that increasing children's attendance to ECEC would require changes at the systemic level of parental leave and flexibility in parents' work arrangements, but also increasing general awareness of the importance of ECEC (Karila, Kosonen, Järvenkallas 2017: 113). This can be bolstered, among other things, with research-based evidence on the effects of attending ECEC.

\section{Organization of ECEC and Pre-Primary Education}

\section{ECEC in day care centers}

ECEC in day care centers (public and private) strongly relies on multi-professional teamwork ideology and careful planning of the activity both at the level of ECEC setting and within each child group. Different professional groups complement one another in daily work and create highly competent working teams. The Qualification Requirements for Social Welfare Professionals Act [272/2005]) mandates that at least one in every three educators in each day care center must be a kindergarten teacher who has a bachelor's degree in education (from a university), or a bachelor's degree in social sciences (from a university of applied sciences). Other educational staff, for instance practical nurses, must at least have a vocational uppersecondary qualification in the field of social welfare and health care. There is no difference in staff qualification requirements between younger and older children's groups. Currently, there is a lack of qualified kindergarten teachers with pedagogical training (university degree) in Finland and the situation is particularly problematic in the metropolitan area. To compensate the need for teachers, universities have been granted additional funding to increase the intake and training of kindergarten teachers in the years 2018-2021 (Ministry of Education and Culture 2017).

The adult-child ratio in day care centers is also regulated by law (Early Childhood Education and Care Act 580/2015). The ratio varies according to children's age and the type of attendance as follows: there has to be one qualified staff member per four children under 3 years of age in full-day care, whereas the adult-child ratio is 1:8 with children above 3 years of age in full-day care. For children above three years of age in part-time care, the adult-child ratio is 1:13. Group size is not separately regulated, but it is rather determined via the adult-child ratio.

Group size relates centrally to the debate regarding learning and upbringing environments suitable for young children (Raittila, Siippainen 2017: 291). At the same time, group size is a matter of maintaining a certain level of costs and thus it relates to the economic debate. Since the law does not directly regulate the maximum group size in day care centers, substantial flexibility can appear in how many children and adults are placed in one group in reality, as the municipalities can determine the group structure independently (Karila, Eerola, Alasuutari et al., upcoming). 
Typically, children are divided into groups in day care centers by their age. Most often there are separate groups for 0-3-year-olds and for 3-6-year-olds, but group structure is highly dependent on the age structure of the children within one setting during the given year/term and/or pedagogical planning. For instance, in some day care centers the so-called "flexible child groups" for 2-6-year-olds have been established, in which the children can grow and proceed toward pre-primary education and primary education as part of the same structural group (divided into functional small groups) and without experiencing additional vertical transitions from one age group to another. When there is a large age range within one group, planning age-appropriate rhythm and daily structure becomes very important in terms of how pedagogy is being delivered. The current trend in Finland is to construct groups around the pair work principle in day care centers (Raittila 2013). This means that a pair consisting of one kindergarten teacher and one practical nurse may form a working team, with each having a set number of children (along the regulated adult-child ratio) with whom they work during the day. The large group, thus, is constructed of two or up to three small groups of children with stable staff to work with them, all of which use the same space. Despite providing a good opportunity for more individualized pedagogy with a small group of children, the system requires careful planning and use of spaces. Further, such grouping arrangements are vulnerable to changes, e.g., if a staff member gets ill. Also, due to working in shifts, the most optimal conditions with two staff members with children only take place for a limited number of hours during the day (usually the most active hours during the morning, before lunch). For some small parts of the day the regulated staff-child ratio can actually be exceeded (i.e., early mornings and hours before closing time in the afternoon), as the law allows temporary exceeding of the adult-child ratios, but does not determine for how long the situation can continue.

\section{ECEC in home-based care}

In home-based care, ECEC takes place most often in the childminder's (municipal or private) own home during similar hours to ECEC in day care centers. Home-based care operates in small groups and the advantage is the home-like environment provided for care and education. In home-based care, childminders can take care of up to four children including their own children who are not yet in primary education. Municipal childminders work alone in their own homes, but are supervised by the municipality (usually by the head of the day care center) and often collaborate with other childminders and local public day care centers. Private childminders are self-employed and usually operate with a business name, but they are supervised by the municipality as part of the ECEC services. Currently, there are around 5200 municipal and 1540 private childminders in Finland (FINEEC 2017).

Within home-based care, the competency-based Further Qualification for Childminders (ISCED 3, 72 credits) is recommended, but not compulsory. Also the 
practical nurse's qualification is suitable for staff in home-based care. Other forms of training may also be accepted by the education provider and provided by the municipalities and adult education institutes.

\section{Pre-primary education}

Organizing pre-primary education (up to 700 hours annually) for children in the year preceding the start of their compulsory education became a statutory obligation for the municipalities in 2001. Attending pre-primary education (4 hours a day) also became mandatory for all 6-year-old children in August 2015.

Pre-primary education is most often organized in day care centers (79\%) in a separate pre-primary groups (for 6-year-olds) or in more heterogeneous groups (e.g., for 4-6-year-olds) depending on the ECEC setting. Pre-primary education can also be organized in primary schools (21\%), either in a separate pre-primary class or as a combined class (pre-primary pupils with 1st grade and/or 2nd grade pupils) (Statistics Finland 2012). Pre-primary education is usually provided in the morning hours (e.g., 8:30 am until 12:30 pm), but can be flexibly designed in other ways as well. Over half of the children attending pre-primary education also attend complimentary ECEC before or after the 4 hours of free of charge pre-primary education.

As with ECEC, in pre-primary education, group-size is not regulated either, but there is a general recommendation for the maximum of 20 children per one group. The Core Curriculum for Pre-Primary Education (2016) governs pre-primary education regardless of the setting and, therefore, regulates the content and - to a certain extent - the pedagogical delivery of pre-primary education. Kindergarten teachers who teach six-year-olds, must hold at least a bachelor's degree in education (from a university). Primary school teachers, who must hold a master's degree in education, are also eligible to teach pre-primary classes.

\section{National Guiding System of ECEC and Pre-Primary Education}

Table 1 introduces the laws, decrees, curriculum documents (implemented at different levels) and steering bodies that form the basis of the national guiding system for Finnish ECEC. Legislation is regulating e.g., the adult-child ratios, and staff qualifications. The legislation governing early childhood education and care was originally enacted in the early 1970s (Day Care Decree 1973). A legislative reform led by the Ministry of Education and Culture was completed in 2015, resulting in new legislation (Early Childhood Education Act 2015), alongside which the Day Care Decree (1973) that is still in use, though partially revised e.g., in terms of adult-child ratios. The National Core Curriculum for ECEC (2016) and the Core Curriculum for Pre-Primary Education (2014) steer the implementation and equal provision of ECEC across the nation. Steering, guidance and the development are 
operated by the Finnish National Agency for Education (under the Ministry of Education and Culture) across the whole age range from the early years through basic education. The entity of different regulating elements describes well the decentralized style of regulating Finnish ECEC, which strongly follows the principles of steering through guidance.

Table 1. National regulations and guidance in ECEC

\begin{tabular}{|c|c|c|c|}
\hline & \multicolumn{2}{|c|}{ ECEC in the years prior to compulsory education } & Primary education \\
\hline Ages & $\begin{array}{c}0-6 \text { years } \\
\text { Early childhood education }\end{array}$ & $\begin{array}{c}6 \text { years } \\
\text { Pre-primary } \\
\text { education }\end{array}$ & $\begin{array}{c}\text { 7-8 years } \\
\text { Grades } 1 \text { and } 2\end{array}$ \\
\hline $\begin{array}{l}\text { Type of } \\
\text { curricula }\end{array}$ & \multicolumn{2}{|c|}{$\begin{array}{l}\text { National core curricula } \\
\text { a) ECEC/pre-primary plans drawn locally by } \\
\text { municipalities/cities, } \\
\text { b) unit-specific ECEC/pre-primary plans } \\
\text { drawn up by each unit/centre } \\
\text { c) Individual ECEC/pre-primary plans drawn } \\
\text { up for each child. }\end{array}$} & $\begin{array}{l}\text { National core curriculum } \\
\text { a) local curricula by } \\
\text { municipalities/cities, } \\
\text { b) School curricula } \\
\text { drawn up by individual } \\
\text { schools }\end{array}$ \\
\hline $\begin{array}{l}\text { Name of } \\
\text { document }\end{array}$ & $\begin{array}{l}\text { Core Curriculum for Early } \\
\text { Childhood Education and } \\
\text { Care (2016) }\end{array}$ & \begin{tabular}{|l|} 
Core Curriculum \\
for Pre-Primary \\
Education (2014)
\end{tabular} & $\begin{array}{l}\text { Core Curriculum for } \\
\text { Basic Education (2014) }\end{array}$ \\
\hline Legislation & \begin{tabular}{|l|} 
Children's Day Care Act \\
(36/1973) \\
Children's Day Care Decree \\
(239/1973) \\
Early Childhood Education \\
Act $(580 / 2015)$
\end{tabular} & \multicolumn{2}{|c|}{$\begin{array}{l}\text { Basic Education Act (628/1998) } \\
\text { Basic Education Decree (852/1998) (amend- } \\
\text { ments 2010). }\end{array}$} \\
\hline Ministry & $\begin{array}{l}\text { Ministry of Education and } \\
\text { Culture }\end{array}$ & \multicolumn{2}{|c|}{ Ministry of Education and Culture } \\
\hline $\begin{array}{l}\text { Development } \\
\text { and steering }\end{array}$ & $\begin{array}{l}\text { Ministry of Education and } \\
\text { Culture is responsible for } \\
\text { planning, steering and } \\
\text { monitoring ECEC. }\end{array}$ & \multicolumn{2}{|c|}{$\begin{array}{l}\text { Finnish National Board of Education (FNBE, } \\
\text { subordinate to the Ministry of Education and } \\
\text { Culture) is responsible for the development of } \\
\text { pre-primary, basic and other education. }\end{array}$} \\
\hline
\end{tabular}

Source: own research.

\section{Curriculum as a Tool of National Steering in ECEC}

The objectives and principles for ECEC prior to primary school-age are laid down in two documents: the Core Curriculum for ECEC (2016) and the Core Curriculum for Pre-Primary Education (2014), which are designed to steer equal delivery of ECEC and pre-primary education across the country. The current Core Curriculum for Basic Education was launched in 2014. These three core curricula aim toward equality in implementing ECEC, pre-primary education and basic education. This means that ECEC, even for the youngest children (children under the age of three), 
is also a solid part of the educational system, normatively regulated and purposefully designed to cover the pedagogically-oriented entity of education, teaching and care.

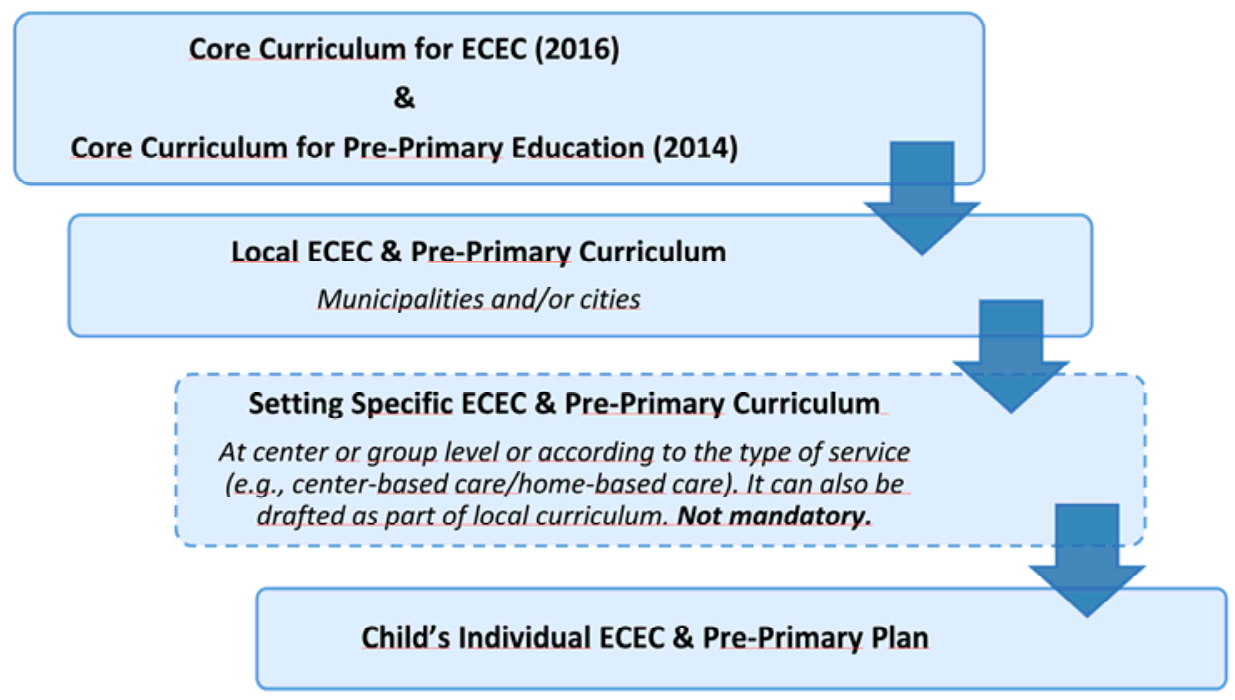

Figure 2. Steering ECEC through curricular implementation

Source: own research

Organization of the curriculum documents represents the national strategy of steering ECEC through guidance (see: Figure 2). Both national curricula are binding to municipalities when they draw up their local ECEC or pre-primary curricula. Municipalities and/or cities can make local amendments to their curricula, but they cannot rule out the contents addressed in the national core curricula. For instance, ECEC in a metropolitan area can have different emphases compared to a rural area in northern Finland, due to geographical location and the expectations of the local community. At the beginning of 2017 there were 311 municipalities (out of which 106 referred to themselves as cities) in Finland (Kuntaliitto 2017), which indicates that there is substantial amount of local variation and freedom also in the ECEC curricula.

Based on local ECEC curricula, municipalities can further draw up city-specific curricula for each ECEC setting, different forms of ECEC provision (i.e., ECEC in day care centers, home-based-care, residents' parks, club activities) or covering both broader local contents as well as contents or preconditions specific for each setting or form of ECEC provision. However, drawing up curriculum at this level is not mandatory. An individual ECEC plan is prepared for each child as a joint collaboration between ECEC staff and the child's parents/guardians. The aim of the individual plan is to enhance children's and parents'/ guardians' participation in ECEC and 
to determine the pedagogical ways of acknowledging the child's individual needs, and further how to implement pedagogy that meets these individual demands along with the group level needs. The Core Curriculum for ECEC (2016: 10-11) particularly emphasizes the role of the child's individual plans and pedagogical documentation in designing the pedagogy both at individual and at group levels.

As mentioned earlier, ECEC is a shared endeavor of parents/guardians and ECEC staff (Core Curriculum for ECEC 2016: 33). The collaboration between parents/guardians is updated in daily exchanges while children are brought to ECEC and picked up, but more deliberately while preparing the individual ECEC/preprimary plan for the child. Collaboration with parents/guardians aids in understanding the multifaceted situations in the families and exploring the best ways of supporting the child both at home and in ECEC. The Core Curriculum for ECEC (2016) emphasizes parental involvement and participation in their child's ECEC more strongly than its predecessor, which had induced plenty of discussions among the ECEC staff. Parental participation is not always easily understood, not to mention conducted as part of daily practice.

\section{Curriculum contents and goals}

The Core Curriculum for ECEC was issued by the Finnish National Agency of Education (EDUFI) in 2016, replacing the previous curriculum (The National Curriculum Guidelines on ECEC in Finland), which had been in force from 2005. The Core Curriculum for ECEC (2016) is a legal norm, which applies to different forms of ECEC across the whole country. The document emphasizes the holistic nature of ECEC comprising education, teaching, and care and highlights the importance of staff's pedagogical knowledge and practices in planning and implementing ECEC in daily work with children. The balance between education, teaching, and care may change depending on the age of the children, indicating the need for basic care as more essential for very young children, which, nevertheless, does not exclude the presence of the elements of early learning.

Functional approaches and methods (i.e., play, exploration, movement and artistic experiencing) that encourage children's creativity and participation are considered as natural ways of learning for children (The Core Curriculum for ECEC 2016: 36-38). ECEC pedagogy encourages active participation of all children in ECEC, which is visible at the level of planning, but also in daily interaction and activities within children groups. The learning conception of the child (ibidem: 20) creates the basis for encountering the child and directs pedagogical planning at many levels. Children are seen as active agents, who learn and develop in interaction with people and their close environments. Children's curiosity together with their previous experiences, understanding and knowledge shape their learning in ECEC and are encouraged by providing possibilities for motivating exploration through multiple modalities and by integrating several areas together. Playing is 
central for children's learning in ECEC. It motivates and produces enjoyment, which simultaneously supports learning skills and acquiring knowledge. Playing in itself is valuable to a child, but should also be used pedagogically.

The goal setting in The Core Curriculum (2016) is constructed through joint objectives, emphasizing the different areas, central to young child's development, by respecting the learning conception of the child. Instead of having specific content areas (comparable to school subjects), five more broad objectives are addressed: 1) Rich world of language, 2) Diverse forms of expression, 3) Me and our community, 4) Exploring and interacting with my environment, and 5) I grow, move and develop (ibidem: 39-47). It is worth emphasizing that even though the objectives are carefully stipulated in the curriculum, there are no official or regulated learning standards in use that children need to meet at the end of ECEC (ibidem: 60). Rather than that, the five objectives presented below structure the ECEC staff's pedagogical work and provide preconditions for both short- and long-term planning and evaluation.

1) Rich world of language - encompasses the important goal of ECEC in enhancing children's language skills and competences and supporting their developing language identities. In practice, this means that children's initiations (nonverbal and verbal) are being heard and acknowledged, to support their engagement with interactional culture. Language is used to model ongoing activities and children are encouraged to use language in different situations. Songs, rhymes, stories and unhurried interaction support developing language skills.

2) Diverse forms of expression - encompasses children's natural ability to express themselves via different modalities. In daily practice this means providing children with ample opportunities to express themselves via musical (e.g., singing, rhyming, dancing and using imagination e.g., in music painting), visual (e.g., painting, drawing, constructing, making multi-media presentations), verbal and physical (children's literature, circus, theater) forms. The significant role of culture in children's lives is encouraged through possibilities to see and experience different forms of culture and arts.

3) Me and our community - encompasses supporting children as their surrounding spheres of life expand and within which children meet diverging opinions and ways of acting. Ethical thinking is encouraged e.g., by jointly discussing the rules of the child group or matters of right and wrong in daily situations. Themes of different religions and life philosophies are approached e.g., through holidays throughout the year or different approaches to food or dressing, in close collaboration with families. Children are encouraged to think about the events in the surrounding society (past, present, and future) for instance by envisioning future life through children's dream jobs or by reflecting on the historical events of past generations. Children's emerging understanding toward media contents is supported and issues relevant to them can be elaborated e.g., via methods related to drama or play. 
4) Exploring and interacting with my environment - encompasses the support for children's ability to observe, structure, and understand their environment. Mathematical thinking is actualized via the observations of the daily surroundings and mathematical phenomena within them. Comparing, classifying, and organizing objects as well as the use of different rhymes, games and measuring activities emerge naturally alongside daily activities. By using an exploratory way of searching their environment, children are also encouraged to think about how technology is created and run by people, and how technological devices in their surroundings function and why. Children are introduced to their environments and their relationship with nature is supported with trips to forests, identifying animals and plants as well as directing children toward the principles of sustainable development (e.g., discussing throwing away food during mealtime).

5) I grow, move and develop - encompasses the goal of facilitating a healthy way of life. Physical activity is encouraged both indoors and outdoors as a natural and deliberate part of the day in order to foster children's joy of movement. Multifaceted physical activities are used, such as outdoor games, trips to the forest, physical activities inspired by music or stories. Children's understanding of a healthy diet is developed by exploring the different tastes and textures of food. Practicing eating in relaxed and unhurried atmosphere encourages children's independence. Children's broader sense of health and safety are encouraged both within ECEC and outside, e.g., practicing maintaining private hygiene, healthy relationships and moving safely around the neighborhood.

The ever-changing society requires new and transferrable skills from children that allow them to flexibly discover solutions to problems and integrate the learned contents. Therefore, ECEC strives to support children's transversal competencies that combine children's developing skills acquired along the five joint objectives by associating these contents to larger and more broadly applicable competencies. The construct of transversal competencies runs in a similar way throughout the curricula for ECEC, pre-primary, and primary education, thus solidifying the continuity in supporting children's learning and involvement in the society.

The Core Curriculum for Pre-Primary education was approved in its revised form by the Finnish National Agency of Education (EDUFI) in 2014. Pedagogy in pre-primary education follows very closely the pedagogical underpinnings in ECEC. Curricular continuity is also highly aligned: for instance, conception of learning, value-basis, working methods and approaches have a highly similar structure in both curricula. In a similar fashion, the continuity is evident in the formulation of joint objectives and transversal competencies in ECEC and in pre-primary education. Therefore, together, the two aligned curricula address the issues of lifelong learning and educational continuity across early childhood and all the way to primary school, a perspective that is particularly strongly built into the educational thinking in Nordic countries (Karila 2012: 588). 


\section{Curriculum and quality}

In the literature concerning quality in ECEC, curriculum is often related to the process quality characteristics of ECEC, particularly in terms of implementation of curriculum and decision making that directly impact children's daily experiences (e.g., Moser et al. 2017). At the country level in Finland, normative core curricula provide solid foundation for equal delivery of pedagogy across the country. Furthermore, there is systematic teacher education in place, which is a rather popular field of studies and thus adds motivated and suitable staff into the field of ECEC. In general, Finnish society relies on ECEC staff's professional competency and the idea that highly qualified professionals provide high-quality education and care is largely accepted (Karila 2010). Staff in Finnish ECEC have become accustomed to a high degree of freedom in choosing how to implement the daily pedagogy along the national core curricula. At the same time, it must be acknowledged that the high degree of freedom also allows for great variation in practice. Consequently, a large scale study has identified significant variation particularly in pedagogical quality in ECEC (Hujala, Fonsén, Elo 2012), indicating that curriculum and pedagogy are not delivered in as equal a manner as the general perception has suggested. The evaluation of Finnish pre-primary education has also revealed differences in quality, which mainly appear between individual settings and to some extent between different geographical areas (ibidem). Municipalities throughout the country are therefore using a lot of effort to establish revised local curricula and transfer them into practice by supporting the ECEC staff in all forms of ECEC.

In Finnish ECEC, systematic compulsory national quality monitoring or inspections are not in practice (ibidem), but rather, a range of quality monitoring methods are applied across the country. It is typical to use quality monitoring frameworks and tools that are originally developed for businesses rather than for educational settings, particularly at the level of service providers. Also, a wide range of user feedback questionnaires are applied at the level of settings, such as questionnaires addressed to parents of the children in ECEC (Mikkola, Repo, Vlasov et al. 2017). Thus, there is a large variation in ways in which the quality is monitored and in purposes for which the information is gathered (ibidem). As the new ECEC legislation came into force in 2015, and as the ECEC services were switched from under the Ministry of Social Affairs and Health to the Ministry of Education and Culture in 2013, the monitoring responsibilities were rearranged simultaneously. The Finnish Education Evaluation Centre (FINEEC) became responsible for evaluating the quality of ECEC along the other levels of education system. To ensure their new task, a working group has been nominated for years 2017-2019 that strives to explore the current state of affairs regarding the quality monitoring in ECEC in Finland, produce a model for quality evaluation (mainly self-evaluation) in ECEC, and further support local service providers in their task of using the model in 
practice. Over time, the model can increase not only the compliance of law and curriculum, but above all the delivery of high quality ECEC and staff's professional competency.

\section{Current Trends and Concluding Remarks}

The main strength of the Finnish ECEC system lies in providing integrated education, teaching, and care for all children under school age in varying, accessible forms, from which parents guardians can choose the best alternative for their family. Furthermore, ECEC in Finland has qualified staff and a normative curriculum in place for all age groups prior to school age, which leads to purposeful delivery of pedagogically-oriented ECEC also for the youngest children participating in the system. Accordingly, ECEC operates along the principles of shared pedagogical planning and a holistic approach toward learning and development with a relatively high degree of freedom for staff to deliver daily pedagogy.

At the same time, some tensions and areas of further improvement in ECEC have emerged, also referred to in this article. Two current issues in particular have received recent national attention. The first issue relates to implementing the normative Core Curriculum (2016) across the country and in all forms of ECEC services (e.g., center- and home-based care, clubs, flexibly scheduled ECEC) to produce high quality and equal ECEC for all children. The variation in circumstances under which the ECEC is being delivered in municipalitiesis large: for instance, in terms of complexity and versatility of the ECEC services within a municipality, staff qualifications, ECEC environments and groupings in different forms of ECEC. Nevertheless, the core curriculum emphasizes equal delivery and suggests that goals, contents and principles are implemented alike everywhere. Consequently, national attention is drawn to how the core curriculum (2016) has been realized and implemented in municipalities. The Finnish Education Evaluation Centre (FINEEC) has started an evaluation process (2017-2019) to produce information on how clear and appropriate for their purpose the different actors consider the national core curriculum for early childhood education and the steering of its implementation to be, and to identify factors that promote or prevent the realization of the national core curriculum for early childhood education and local plans. At best, this enables the possibility to even out variation in pedagogical quality across different forms of ECEC, across private and public service providers, as well as across municipalities, by producing information on local interpretations of the core curriculum document and the realization of these interpretations in early childhood education practices.

Secondly, some tensions also relate to ECEC workforce, namely, to clarifying the roles of different professional groups working in the field of ECEC, and to maintaining and supporting the professional workforce (Karila, Kosonen, Järven- 
kallas 2017). For instance, kindergarten teachers are currently educated both at the universities and universities of applied sciences, but the content of teacher education is not the same. Among other things, kindergarten teachers graduating from universities of applied sciences do not have a qualification to teach in pre-primary education and their education focuses more on social aspects of ECEC work, whereas university education provides more nuanced understanding of pedagogy and is more research-based. Current discussion particularly evolves around the question of whether kindergarten teachers from both educational backgrounds are equally competent to deliver pedagogically-oriented ECEC, as it is considered a key aspect of high quality ECEC and explicitly highlighted in the normative Core Curriculum (2016). Simultaneously, more complex work with children and parents in ECEC and in the changing society requires the professional competence of kindergarten teachers with both educational backgrounds. Hence, the professional strengths of both educational backgrounds should be better acknowledged in the daily work and the complementary nature of the two moved to the center of the discussion. Consequently, the biggest challenge for the future is to discuss and elaborate the professional roles more clearly (also in the legislation), and this further indicates pressures to also develop teacher education. On a final note, ECEC in Finland largely relies on educated staff. Thus, a need to support the workforce has been acknowledged more systematically. A careful, continued and stable professional development system at the national level and local levels during the coming years can help safeguard high quality ECEC also in the future (Karila, Kosonen, Järvenkallas 2017).

Despite having good reputation and relatively high quality of structural and process characteristics in Finnish ECEC, certain tensions and challenges continue to prevail. A recently published report, the roadmap on the development of early childhood education for 2017-2030 (ibidem) provides the overall understanding on the current state of affairs in Finnish ECEC and suggests how key aspects of the ECEC system should be developed over the following decade. Large national evaluation initiatives have also been launched just recently, namely, the work of FINEEC on the issues of curriculum (2016-2019a) and quality (2016-2019b). These initiatives together indicate systematic and long-term processes and ambitions to support the development of ECEC in Finland and to safeguard high quality early education, teaching, and care for children also in the future.

\section{References}

Asetus lasten päivähoidosta [Children's Day Care Decree] (239/1973) Helsinki, Suomen laki ja asetuskokoelma.

Core Curriculum for Early Childhood Education and Care (2016) Helsinki, Finnish National Agency of Education. 
Core Curriculum for Pre-Primary Education (2014) Helsinki, Finnish National Agency of Education.

Eerola-Pennanen P., Vuorisalo M., Raittila R. (2017) Johdatus varhaiskasvatukseen [Introduction to early childhood education and care] in: Valloittava Varhaiskasvatus [Charming Early Childhood Education and Care: Learning, participation and wellbeing], M. Koivula, A. Siippainen, P. Eerola-Pennanen (eds.) Tampere, Vastapaino: 12-25.

Hujala E., Fonsén E., Elo J. (2012) Evaluating the quality of the child care in Finland, "Early Child Development and Care", 3-4: 299-314.

Hänninen S.-L., Valli S. (1986) Suomen lastentarhatyön ja varhaiskasvatuksen historia [History of Finnish kindergartens and early childhood education and care], Helsinki, Otava.

Karila K. (2010) A Finnish viewpoint on professionalism in early childhood education in: Professionalism in Early Childhood Education and Care. International Perspectives, C. Dalli, M. Urban (eds.), New York, Routledge. (The book is a reproduction of the "European Early Childhood Education Research Journal", 2: 80-92).

Karila K. (2012) A Nordic Perspective on Early Childhood Education and Care Policy, "European Journal of Education", 45: 84-595.

Karila K., Eerola P., Alasuutari M., Kuukka A., Siippainen A. (upcoming) Varhaiskasvatuksen järjestämisen puhekehykset kunnissa [Frames for organizing ECEC in municipalities], Manuscript under revision.

Karila K., Kosonen T., Järvenkallas S. (2017) Roadmap on the development of early childhood education for 2017-2030. Guidelines for increasing the degree of participation in early childhood education, and for the development of the skills of daycare centre staff, personnel structure and training, Publications of the Ministry of Education and Culture, Helsinki.

Lahtinen J., Selkee J. (2014) Varhaiskasvatuksen hallinto, palveluseteli ja kuntalisät 2014 [ECEC administration, day-care service voucher and municipal suppliments in 2014], Helsinki, Kuntaliitto.

Laki lasten päivähoidosta [Children's Day Care Act] (36/1973) Helsinki, Suomen laki ja asetuskokoelma.

Laki sosiaalihuollon ammatillisen henkilöstön kelpoisuusvaatimuksista [Act on Qualification Requirements for Social Welfare Professionals] (272/2005), Helsinki, Suomen laki ja asetuskokoelma.

Määttä K., Uusiautti S. (2012) How do the Finnish family policy and early education system support the well-being, happiness, and success of families and children?, "Early Child Development and Care", 3-4: 291-298. 
Miettunen L. (2008) The role of the Municipal Home Care Allowance in the Finnish child day-care system, Helsinki, The Social Insurance Institution, Finland, Studies in social security and health, 101: 1-126.

Mikkola A., Repo L., Vlasov J., Paananen M., Mattila V. (2017) Varhaiskasvatuksen arvioinnin nykytila [Present state of evaluation in ECEC], Publications of the Finnish Education Evaluation Centre.

Pasila A. (2014) Työ vai perhe? Usein molemmat! [Work or Family? Oftetimes both!], Hyvinvointikatsaus 1/2014. Lasten ja lapsiperheiden elinolot. Hyvinvointitilastollinen aikakauskirja 25. vuosikerta, Helsinki, Tilastokeskus \& Sotkanet.

Puroila A.-M., Kinnunen S., Keränen V. (2017) Varhaiskasvatuksen lainsäädännön uudistamiseen tarvitaan johdonmukaisuutta ja yhteistä tahtoa [Renewal of ECEC legislation reguires consistency and shared will], Valtioneuvoston selvitys-ja tutkimustoiminta, Policy brief $4 / 2017$.

Raittila R. (2013) Pienryhmätoiminta ja leikkialueet: varhaiskasvatuksen pedagoginen toimintaympäristö rakentuu arkisissa käytännöissä [Small group and play area pedagogy: Constructing pedagogical environment in daily practice] in: Varhaiskasvatuksen pedagogiikka [Pedagogy in ECEC], K. Karila, L. Lipponen (eds.), Tampere, Vastapaino: 69-94.

Raittila R., Siippainen A. (2017) Varhaiskasvatuksen pedagoginen toimintaympäristö [Pedagogical environment in ECEC] in: Valloittava varhaiskasvatus: Oppimista, osallisuutta ja hyvinvointia [Charming ECEC: Learning, participation and wellbeing], M. Koivula, A. Siippainen, P. Eerola-Pennanen (eds.), Tampere, Vastapaino: 283-292.

Rutanen N, de Souza Amorim K., Miguel Colus K., Piattoeva N. (2014) What is Best for the Child? Early Childhood Education and Care for Children under 3 Years of Age in Brazil and in Finland, "International Journal of Early Childhood", 2: 123-141.

Rönkä A., Turja L., Malinen K., Tammelin M., Kekkonen M. (2017) Flexibly scheduled early childhood education and care: experiences of Finnish parents and educators, “Early Years", DOI: 10.1080/09575146.2017.1387519.

Säkkinen S., Kuoppala T. (2016) Varhaiskasvatus 2015 [Early Childhood Education and Care 2015], Statistical report, Helsinki, National Institute of Health and Welfare.

Varhaiskasvatuslaki [Early Childhood Education Act] (580/2015) Helsinki, Suomen laki ja asetuskokoelma.

\section{Electronic sources}

Finnish Education Evaluation Centre (FINEEC) (2017) Tilastoraportti: Varhaiskasvatussuunnitelman perusteiden toimeenpanon arviointi [Statistics Report: Evaluation of the national core curriculum for early childhood education], Helsinki, https://karvi.fi/ 
Finnish Education Evaluation Centre (FINEEC) (2016-2019a) Evaluation of the national core curriculum for early childhood education, https://karvi.fi/en/event/ evaluation-national-core-curriculum-early-childhood-education/

Finnish Education Evaluation Centre (FINEEC) (2016-2019b) Supporting early childhood education providers in quality management, https://karvi.fi/en/event/ supporting-early-childhood-education-providers-quality-management/

Heinämäki L. (2008) Early childhood education in Finland. Potsdam, Liberales Institut, http://www.fnf.org.ph/downloadables/Childhood\%20Education\%20in\%20Finland.pdf

Kahiluoto T. (2009) Integration of Education and Care in ECEC: Integration at the System Level: Finland as Example, Presentation for the OECD Early Childhood Education and Care (ECEC) Network, 7th of December 2009, https://studylib.net/doc/ 17843827/integration-of-education-and-care-in-ecec-oecd-7-december

Kuntaliitto (2017) Kaupunkien ja kuntien lukumäärät [Number of Finnish cities and municipalities], https://www.kuntaliitto.fi/asiantuntijapalvelu/kaupunkien-ja-kuntienlukumaarat

Ministry of Education and Culture (2017) 1000 uutta lastentarhanopettajaa [1000 new kindergarten teachers], Press release, 5.9.2017, http://minedu.fi/artikkeli//asset_publisher/tuhat-uutta-lastentarhanopettajaa

Moser T., Leseman P., Melhuish, E., Broekhuizen M., Slot P. (2017) European Framework of Quality and Wellbeing Indicators. WP6.3 Curriculum and quality analysis impact review, CARE, http://ecec-care.org/fileadmin/careproject/Publications/ reports/D6_3_CARE_Framework_of_Quality_and_Wellbeing_Indicators.pdf

National Curriculum Guidelines on Early Childhood Education and Care in Finland (2005) Helsinki, Stakes, www.thl.fi/thl-client/pdfs/7eef5448-e8a3-4887-ab9719719ea74066 (English version 2004).

OECD (2016) Education at a glance: OECD indicators, Paris: OECD publishing, http://dx.doi.org/10.187/eag-2016-en

Statistics Finland (2012) Suomen virallinen tilasto (SVT): Esi- ja peruskouluopetus. [Official Finnish statistics: Preschool and primary education], Helsinki, Tilastokeskus, http://www.tilastokeskus.fi/til/pop/index.html

United Nations (1989) The United Nations Convention on the Rights of the Child, New York, http://www2.ohchr.org/english/law/crc.htm 